\title{
Improving knowledge, skills, and attitudes of the nursing faculty members and postgraduate students towards plagiarism in academic writing
}

\author{
Suzan El-Said Mansour *1, Fawzia El-Sayed Abusaad ${ }^{2}$, Mohamed A. El Dosuky ${ }^{3}$, Adel Al-Wehedy Ibrahim ${ }^{4}$ \\ ${ }^{1}$ Woman's Health \& Midwifery Nursing Department, Faculty of Nursing, Mansoura University, Egypt \\ ${ }^{2}$ Pediatric Nursing Department, Faculty of Nursing, Mansoura University, Egypt \\ ${ }^{3}$ Computer Science Department, Faculty of Computers \& Information, Mansoura University, Egypt \\ ${ }^{4}$ Public Health \& Community Medicine Department, Faculty of Medicine, Mansoura University, Egypt
}

Received: February 3, 2017

DOI: $10.5430 /$ jnep.v7n9p107
Accepted: April 10, 2017

Online Published: April 25, 2017

URL: https://doi.org/10.5430/jnep.v7n9p107

\begin{abstract}
Background and aim: Plagiarism is the use of concepts, words, manuscript and data without acknowledgment of the original source. It has become a worldwide problem, and a contentious matter in university education and research. The study aimed to improve knowledge, skills, and attitudes of the nursing faculty members and postgraduate students towards plagiarism in academic writing.

Methods: A quasi-experimental (pre-post) design. Setting: The study was accomplished at the Nursing Faculty in Mansoura University. Sample: Convenient sample was used included 195 participants (100 nursing faculty members and 95 postgraduate students) of all nursing specialties who attended and completed the educational \& training workshop. Tools: A structured Interviewing Schedule, Attitudes toward Plagiarism Scale and Plagiarism Scenario-Based Questionnaire.

Results: The average score of the participants' knowledge and their practical scenario-solving scores about plagiarism were significantly increased after the training workshop compared to their levels before it. In addition, the average scores of the positive attitude, subjective norms and total attitudes score towards plagiarism were significantly decreased, while the average score of the negative attitude significantly increased after the training workshop in comparison to before it. Moreover, there was a statistically significant positive, moderate correlation between the participants' knowledge score about plagiarism and their practical scenario-solving scores $(r=0.346, p \leq .001)$. In addition, there was a significant positive mild correlation between the total knowledge score and the negative attitude of the studied sample towards plagiarism $(r=0.254, p \leq .001)$.

Conclusions: It was evident that there was a statistically significant improvement in knowledge and skills of the nursing faculty members and postgraduate students with a significant change in their attitudes towards plagiarism after implementation of the workshop. Recommendations: Providing continuing educational and training programs for the newly faculty members and researchers to improve their scientific writing skills, and research ethics and for highlighting plagiarism and its consequences.
\end{abstract}

Key Words: Knowledge, Skills, Attitudes (KSA), Nursing faculty members, Postgraduate students, Plagiarism in academic writing

*Correspondence: Suzan El-Said Mansour; Email: drsuzanelsaid@gmail.com; Address: Woman’s Health \& Midwifery Nursing Department, Faculty of Nursing-Mansoura University, Egypt.

Published by Sciedu Press 


\section{INTRODUCTION}

Plagiarism is a form of academic misconduct which is derived from the Latin word plagiare or kidnapper; which refers to the use of the writings or ideas of somebody else's and claiming them as your own original work, or re-using previously submitted work of one's own. ${ }^{[1]}$ It is the acceptance of original creations of another author without due acknowledgment. $^{[2]}$

Moreover, plagiarism is an illegal action similar to cheating. It can be defined as dishonesty of the critical thinking and the manner of independence that is necessary to increase the knowledge body. ${ }^{[3]}$ There are various types of plagiarism including taking data, tables or figures from previous publications and using it without citation, publish similar documents repeatedly, publish similar article in a local and also in an international journal with different or same authorship. ${ }^{[4,5]}$

In the academic and scientific writing, plagiarism is an important academic problem which is considered a significant offense and is an unacceptable approach. Nowadays, falling into the plagiarism trick became very easy because the availability and expansion of the internet resources that provide all the information needed anywhere. Unfortunately, some of the students and even the faculty members are using these resources in an unacceptable manner and can handle this fault due to lack of the writing skills. In addition to lack of their awareness about the advanced software at the educational institutions that can detect the plagiarism easily. ${ }^{[6]}$

The most important contributing factors to the plagiarism problem are the easy access to the internet resources. However, there are additional reasons such as lack of ethical awareness and cultural aspects, lack of language proficiency and inadequate skills required for using data, such as paraphrasing, citing and referencing. ${ }^{[7]}$ Plagiarism happens as consequence of definite elements in the academic field, notably the pressure to publish. There are other causes such as lack of awareness of plagiarism.

Nursing researches, among the medical-related sciences, is central to the patient management, thus, publishing misconduct-free nursing researches are considered of great importance. Nowadays, academics are armed with plagiarism detection tools such as iThenticate $\AA$, even though sometimes plagiarism detection is cumbersome. ${ }^{[8,9]}$

Particularly, nursing professors are in charge of spreading and preserving the standards of research ethics as the nonfulfillment of these standards may have pernicious consequences on patients' lives. ${ }^{[10]}$ There is an urgent need to identify the knowledge and attitudes of researchers towards plagiarism and scientific misconduct, ${ }^{[11]}$ while plagiarism 108 will never be vanquished until the institutional control is required to reduce it. ${ }^{[12]}$

Additionally, academic misconduct in the scientific nursing researches can seriously harm the people's life and health, so it needs a great accountability. ${ }^{[13]}$ Doing researches and publishing articles is mandatory in academic nursing field for both the faculty members and postgraduate students, since both of them are often under the pressure to publish articles for job promotion, which enforce them to have a certain number of publications in scientific journals. They may attempt to copy and paste from the internet, where a massive amount of data is simply accessible. For avoiding plagiarism, it is important to increase the awareness about the basic principles of the academic writing skills and learn to employ these principles in the academic work. Thus, there is a serious need to identify the awareness level and attitudes of academics towards plagiarism. ${ }^{[14]}$

\subsection{Significance of the study}

Nursing necessitates a great accountability, complete committing, and honest life. Unethical misconduct, including plagiarism in scientific researches may have harmful consequences on peoples' lives. ${ }^{[13]}$

Nursing faculty members are participating in various research projects and disseminate their findings nationally and internationally nevertheless, they may not fully grasp the essence of plagiarism problem and its related aspects. Smedley et al. ${ }^{[15]}$ listed some approaches to promote the research ethics and honesty for eliminating plagiarism rate and its susceptibility.

At Mansoura University, Turnitin has been adopted as a plagiarism checker program to check the scientific researches of the faculty members and postgraduate students. According to the university rules, the plagiarism percentage of any scientific article must not exceed $25 \%$. Consequently, this study is accomplished to improve gained knowledge, skills and attitudes of the nursing faculty members and postgraduate students towards plagiarism in academic writing.

\subsection{Aim of the study}

This study aimed to improve the knowledge, skills and attitudes (KSA) of the nursing faculty members and postgraduate students towards plagiarism in academic writing through the following:

- Identify KSA of the faculty members and postgraduate students towards plagiarism before the intervention.

- Implement an educational and training workshop to improve their (KSA) level.

- Identify the effect of the workshop on their (KSA) 
towards plagiarism.

\subsection{Research hypothesis}

It was expected that the nursing faculty members and postgraduate students who attended the educational and training workshop exhibit an improvement in their knowledge, skills and attitudes towards plagiarism than before.

\subsection{Operational definitions}

Plagiarism: Using of others' terms, concepts and ideas without obviously and appropriately acknowledge the original source of that data.

Academic Integrity: Refers to the practice of academic activity in responsible and truthful way.

Academic Dishonesty: Failure to adhere by the four norms of academic integrity identified in this Code (plagiarism, cheating, collusion and fabrication).

\section{SUBJECTS AND METHOD}

\subsection{Study design}

A quasi-experimental pre-post design was used.

\subsection{Study setting}

This study was accomplished at the Faculty of Nursing, Mansoura University, Egypt.

\subsection{Study subjects}

A convenient sample included all the target subjects who attended the workshop, only 195 participants out of 208 members (consisted of 100 faculty members and 95 postgraduate students of all nursing specialties) completed the workshop and filling the questionnaire (response rate 195/208 =94\%).

\subsection{Data Collection and Scheduling Tools (DCAST)}

The authors extensively reviewed the related national and international literature, and then adopted the following set of DCAST:

Tool I: A Structured Interviewing Schedule Meticulously designed by the authors to be filled by the respondents. It consisted of two parts:

1) The First consisted of general characteristics of studied subjects such as age, gender, academic position, specialty, published articles and attendance scientific writing classes.

2) The Second consisted of seven MCQs and five true and false questions. It was concerned with the evaluation of the knowledge of the faculty members and post-graduate students about plagiarism. It was contained questions such as understanding plagiarism, paraphrasing definitions, legality and ethics of plagiarism and how to avoid plagiarizing

Published by Sciedu Press material, with score (1) for correct answers, and score (0) otherwise; the total score range was from zero (no answer is correct) to twelve (all answers are correct).

Tool II: Attitudes toward Plagiarism Scale (ATP) Developed by Mavrinac et al. ${ }^{[16]}$

It is consisted of 29 items used to measure and evaluate the ATP. It includes three attitudinal factors:

- Positive attitude: Consists of twelve statement to measure the degree of individuals acceptance of plagiarism and actions which done by themselves.

- Negative attitude: Consists of seven statements to measure the degree of condemnation of plagiarism actions that done by others.

- Subjective norms: Consists of ten statements to measure the degree of society acceptance degree to plagiarism.

The nursing staff and postgraduate students responded to each item by using a 5-point Likert scale as a continuum from "strongly disagree" quantified as (1), through "disagree", "neither agree or disagree", "agree", "strongly agree" quantified as (5). The score for each attitudinal factor was calculated by summing. Then, the range of every factor was allocated into three equivalent parts representing low, moderate and high score.

\begin{tabular}{ll}
\hline \multirow{2}{*}{ Positive Attitude } & Low 12-28* \\
& Moderate 29-45 \\
& High 46-60 \\
\hline \multirow{3}{*}{ Negative Attitude } & Low 7-16 \\
& Moderate 17-26 \\
& High 27-35* \\
\hline \multirow{3}{*}{ Subjective Norms } & Low 10-23* \\
& Moderate 24-37 \\
& High 38-50 \\
\hline
\end{tabular}

Tool III: Plagiarism Scenario-Based Questionnaire Adopted from Introduction to Transfusion Science' by Overfield et al. (1999). It was used to evaluate the skills and practices of the participants towards plagiarism. It was employed successfully to engage the studied group in the learning process. The core idea behind these scenarios is to provide original paragraphs derived from scientific textbooks, showing the proper ways to cite provided information while avoiding plagiarism. The questionnaire consisted of four case scenarios with single \& multiple response items and the participants have to identify which student was guilty of plagiarism by response either Yes/No. The total choices are 12 situations, so the total score ranges from zero (no answer is correct) to 12 (all answers are correct). ${ }^{[1]}$ 


\subsection{Development of the study tools validity \& reliability}

Three experts of university professors specialized in nursing reviewed the tools for affirming the content validity. While its reliability was tested by using Cronbach's $\alpha$. Reliability for Tool I $=0.732$, test retest $(r)=0.697, p \leq .001$ and Cronbach's $\alpha$ for Tool III $=0.741$, test retest $(r)=0.821, p \leq .001$. According to Mavrinac et al., ${ }^{[16]}$ the reliability of tool II was calculated to affirm the reliability: factor I positive ATP (12 items); $-\alpha=0.83$; factor II negative ATP (7 items); $-\alpha=0.79$; and factor III subjective norms toward plagiarism (10 items). $-\alpha=0.85$. Correlations between factors were: -0.37 between II and I, -0.41 between I and III, and +0.31 between II and III. Hence, the tools were found to be highly reliable.

\subsection{Pilot study}

Twenty participants were engaged in the pilot study and not included in the research sample, consisted of about 2-3 participants selected from eight scientific departments at the nursing faculty after the announcement of the workshop. It used to achieve the following objectives:

- Assess feasibility and preliminary testing of the study hypothesis;

- Checking whether the study tools are both applicable and relevant or not;

- Checking if the designed tools are clear or not; and

- Estimating the time needed to conduct the sessions and to answer each tool.

Finally, all required amendments were done.

\subsection{Data collection procedure}

- This study was carried out during the period from June to September 2016.

- The researchers had announced about implementation of the educational \& training workshop regarding how to avoid plagiarism in academic writing. The announcement was done before two weeks of the workshop time through an official announcement clarified the date, title and place of the workshop. The announcement has done through using an official electronic webpage of the electronic learning unit at the nursing faculty after obtaining the dean approval.

- The workshop was held at the conference hall on the first floor at the nursing faculty.

- The researchers introduced themselves to the faculty members and the postgraduate students, and explained the aim of the study before the data collection. They were also informed that they could withdraw from the study at any time without giving any justification.

- The overwhelming audience spanned over a bulk of the faculty members and the postgraduate students. The density of eager audience may be comprehended in the context of plagiarism policy and regulations recently adopted in Mansoura University.

- An educational \& training workshop was done in one day and was repeated twice to cover the attendee; each day is divided into one theoretical session and two practical training sessions.

- Before the first session, pretest was done to assess the knowledge, skills and attitudes of the participants regarding plagiarism by using the predetermined tools.

- An interactive multi-session was conducted with all the respondents to educate them about plagiarism using multimedia, PowerPoint presentation and group discussion for two hours each about (definition, types, causes of plagiarism and the methods used to avoid it, the concept of academic integrity and consequences of research misconduct).

- At the practical sessions, the researchers were conducted training sessions by using case study scenarios and train them about different methods used to avoid plagiarism such as paraphrasing, summarizing, citing, how to keep careful records of sources, use various sources to ensure a variety of content and checking the manuscript for inadvertent plagiarism using Turnitin, or iThenticate or other detection tools.

Educational and training materials used. Multimedia and PowerPoint presentation are available for download from the third author's website. http: $/ / \mathrm{m} \cdot$ el-dosuky. com/course.php?c=plagiaris m-avoidance-and-scientific-writing The educational process followed many allegories, such as the Bee Allegory in which a bee slurps nectar from flowers then syntheses into honey, as a metaphor for the effective scientific writing process. To avoid plagiarism, the talk hints to time management and gives examples on quoting, paraphrasing, summarizing, and drawing figures.

- Then, posttest was done at the end of the workshop to evaluate knowledge, skills and attitudes of the participants (see Figure 1).

\subsection{Statistical analysis}

The data were collected, coded, computed and statistically analyzed using SPSS version 21.0. Quality control was done at the stages of coding and data entry. Data was presented using descriptive statistics in the form of frequencies and percentages for qualitative variables, means and standard deviations for quantitative variables. Quantitative variables were compared by using paired $(t)$ test and student $(t)$ test meanwhile, $\chi^{2}$ test was used to compare the Qualitative 
variables. Correlation coefficient (r) was done to find corre- significance was considered at $p$-value $<.05$.

lation between two quantitative variables. Cronbach's $\alpha$ is used for test score reliability measure of sample. Statistical

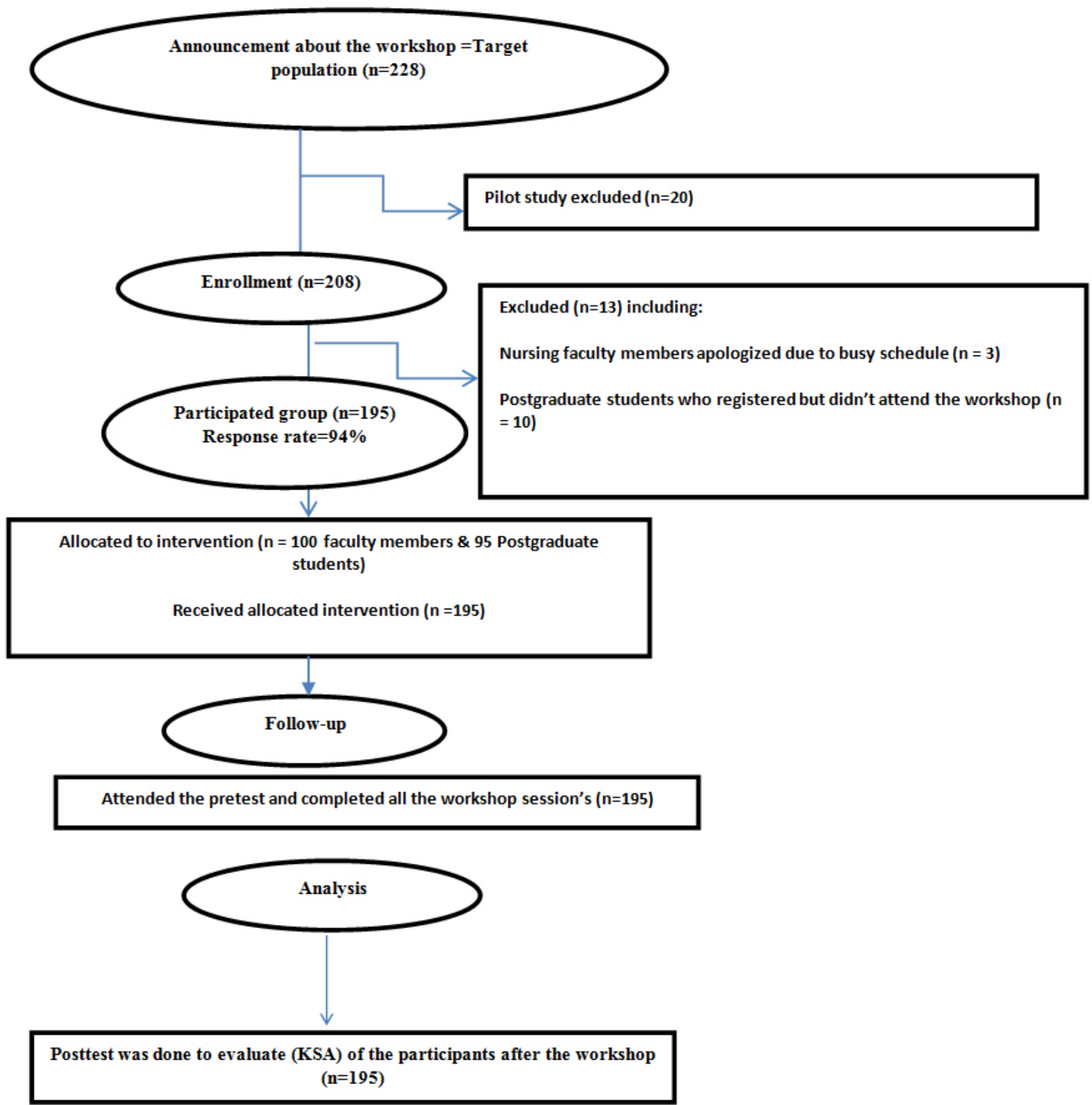

Figure 1. Flowchart of the research process

\subsection{Ethical considerations}

Written consent was obtained from the dean of nursing faculty to conduct the study, staff members and the postgraduate students who participated in the study were reassured about the confidentiality of the information, their rights to refuse participation or withdraw at any time and the study maneuvers could not entail any harm to participants.

\section{RESULTS}

Characteristics of the studied sample are shown in Table 1. The age of the study participants ranges from 24-45 years with average $30.64 \pm 4.66$ years. Most of them were females (92.3\%), and distributed in eight nursing specialties. As regards the academic position, demonstrators represent $33.8 \%$, assistant lecturer $47.7 \%$, lecturer $16.9 \%$ and assistant 
professors $1.5 \%$. Their years of experience range from less than 5 years $(36.4 \%), 5-10$ years $(37.9 \%)$ to more than 15 years $(25.6 \%)$.

Figure 2 shows that, the percentage of the published articles was $63.1 \%$, attending scientific writing classes $(56.7 \%)$, research ethics training $(41.5 \%)$ and getting information about plagiarism was $16.4 \%$.

Table 2 represents the average knowledge and skills score of the studied sample before and after the training workshop. The average score of the participants' knowledge and their practical scenario-solving scores about plagiarism were significantly increased after the training workshop compared to their levels before it.

Tables 3-5 show the positive, negative and subjective norms attitudes of the studied sample towards plagiarism pre- and post- the workshop. There was a significant change in all items of the three factors of attitudes among the participants. The response to the positive attitude items tend to decrease, the response to the items of the negative attitude tend to increase while the response to the items of the subjective norms attitude tend to decrease.

Table 6 shows the average attitudes score of the studied sample towards plagiarism pre- and post- the workshop. The average scores of the positive attitude, subjective norms and total attitude score towards plagiarism were significantly decreased after training, while the average score of the negative attitude significantly increased after the training workshop in comparison to before it.

Table 1. Frequency distribution of the general characteristics of the studied sample

\begin{tabular}{|c|c|c|c|}
\hline \multirow{2}{*}{ Characteristics } & \multirow{2}{*}{ Items } & \multicolumn{2}{|c|}{$N=195$} \\
\hline & & $\mathbf{N}$ & $\%$ \\
\hline \multirow{4}{*}{ Age Group } & $24-29$ & 84 & 43.1 \\
\hline & $30-39$ & 101 & 51.8 \\
\hline & $40-45$ & 10 & 5.1 \\
\hline & Mean \pm SD & \multicolumn{2}{|c|}{$30.64 \pm 4.66$} \\
\hline \multirow{2}{*}{ Sex } & Male & 15 & 7.7 \\
\hline & Female & 180 & 92.3 \\
\hline \multirow{8}{*}{ Nursing Specialty } & Medical/surgical & 36 & 18.5 \\
\hline & Maternity & 30 & 15.4 \\
\hline & Pediatrics & 27 & 13.8 \\
\hline & Psychiatry & 15 & 7.7 \\
\hline & Administration & 24 & 12.3 \\
\hline & Geriatric & 18 & 9.2 \\
\hline & Critical & 19 & 9.7 \\
\hline & Community & 26 & 13.3 \\
\hline \multirow{4}{*}{ Academic Position } & Demonstrator & 66 & 33.8 \\
\hline & Assist. lecturer & 93 & 47.7 \\
\hline & Lecturer & 33 & 16.9 \\
\hline & Assist. professor & 3 & 1.5 \\
\hline \multirow{3}{*}{ Education } & Bachelor & 66 & 33.8 \\
\hline & Master & 93 & 47.7 \\
\hline & Doctorate & 36 & 18.5 \\
\hline \multirow{3}{*}{ Experience } & $<5$ years & 71 & 36.4 \\
\hline & 5-10 years & 74 & 37.9 \\
\hline & $>10$ years & 50 & 25.6 \\
\hline
\end{tabular}

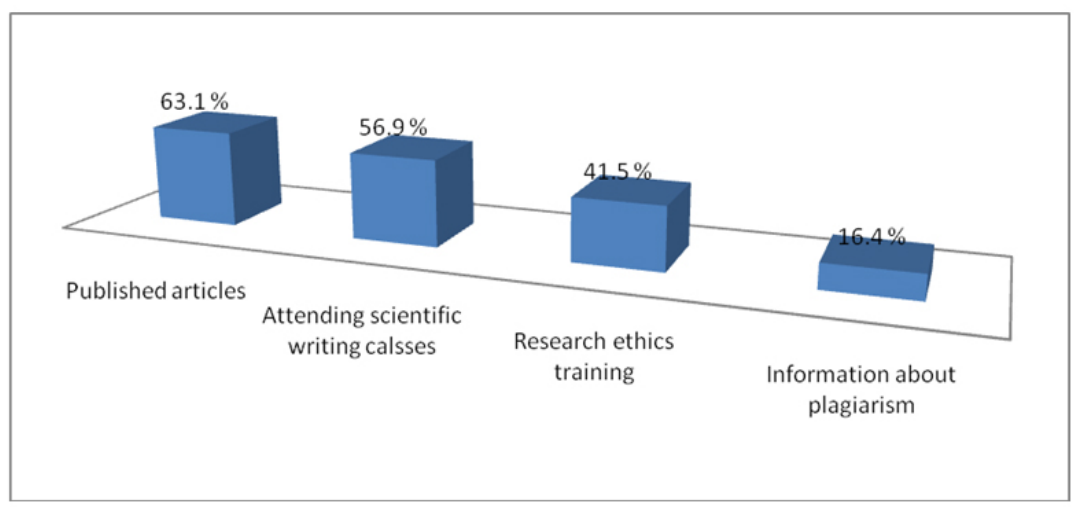

Figure 2. Frequency distribution of the training programs attended by the studied sample

Table 2. Average knowledge and skills score of the studied sample pre- and post- the training workshop

\begin{tabular}{llll}
\hline \multirow{2}{*}{ Items } & Pre-Training & Post-Training & \multirow{2}{*}{ Paired $\boldsymbol{t}$ test } \\
\cline { 2 - 4 } & Mean \pm SD & Mean \pm SD & $t=37.251, p \leq .001$ \\
\hline Knowledge score & $4.41 \pm 1.68$ & $8.64 \pm 1.46$ & $t=30.572, p \leq .001$ \\
Skills score (practical scenarios-solving) & $3.85 \pm 1.81$ & $7.58 \pm 1.75$ & $t$ \\
\hline
\end{tabular}


Table 3. Frequency distribution of positive attitude towards plagiarism of the studied sample pre- and post- the training workshop

\begin{tabular}{|c|c|c|c|c|c|c|c|}
\hline \multirow{2}{*}{ Items of Positive Attitude } & \multirow{2}{*}{ SG } & \multirow{2}{*}{$\begin{array}{l}\text { SD } \\
\text { N (\%) }\end{array}$} & \multirow{2}{*}{$\begin{array}{l}\text { D } \\
\text { N (\%) }\end{array}$} & \multirow{2}{*}{$\begin{array}{l}\text { Either } \\
\mathrm{N}(\%)\end{array}$} & \multirow{2}{*}{$\begin{array}{l}\text { A } \\
\mathrm{N}(\%)\end{array}$} & \multirow{2}{*}{$\begin{array}{l}\text { SA } \\
\text { N (\%) }\end{array}$} & \multirow{2}{*}{$\begin{array}{l}\text { Significance } \\
\text { test }\end{array}$} \\
\hline & & & & & & & \\
\hline \multirow{2}{*}{$\begin{array}{l}\text { 1. Sometimes one cannot avoid using other people's } \\
\text { words without citing the source }\end{array}$} & Pre & $74(37.9)$ & $62(31.8)$ & $24(12.3)$ & $31(15.9)$ & $4(2.1)$ & \multirow{2}{*}{$\begin{array}{l}\chi^{2}=55.170 \\
p \leq .001\end{array}$} \\
\hline & Post & $39(20.0)$ & $32(16.4)$ & $27(13.8)$ & $63(32.3)$ & $34(17.4)$ & \\
\hline \multirow{2}{*}{$\begin{array}{l}\text { 2. Justified to use previous description of a method, } \\
\text { because the method itself remains the same }\end{array}$} & Pre & $10(5.1)$ & $23(11.8)$ & $50(25.6)$ & $90(46.2)$ & $22(11.3)$ & \multirow{2}{*}{$\begin{array}{l}\chi^{2}=45.510 \\
p \leq .001\end{array}$} \\
\hline & Post & $18(9.2)$ & $61(31.3)$ & $66(33.8)$ & $39(20.0)$ & $11(5.6)$ & \\
\hline \multirow{2}{*}{$\begin{array}{l}\text { 3. Self-plagiarism is not punishable because it is not } \\
\text { harmful }\end{array}$} & Pre & $11(5.6)$ & $19(9.7)$ & $18(9.2)$ & $98(50.3)$ & $49(25.1)$ & \multirow{2}{*}{$\begin{array}{l}\chi^{2}=90.560 \\
p \leq .001\end{array}$} \\
\hline & Post & $22(11.3)$ & $97(49.7)$ & $13(6.7)$ & $41(21.0)$ & $22(11.3)$ & \\
\hline \multirow{2}{*}{$\begin{array}{l}\text { 4. Plagiarized parts of a paper may be ignored if the } \\
\text { paper is of great scientific value }\end{array}$} & Pre & $16(8.2)$ & $13(6.7)$ & $19(9.7)$ & $76(39.0)$ & $71(36.4)$ & \multirow{2}{*}{$\begin{array}{l}\chi^{2}=99.570 \\
p \leq .001\end{array}$} \\
\hline & Post & $34(17.4)$ & 87 (44.6) & $13(6.7)$ & $25(12.8)$ & $36(18.5)$ & \\
\hline \multirow{2}{*}{$\begin{array}{l}\text { 5. Self-plagiarism should not be punishable in the } \\
\text { way as plagiarism }\end{array}$} & Pre & $12(6.2)$ & $15(7.7)$ & $13(6.7)$ & $65(33.3)$ & $90(46.2)$ & \multirow{2}{*}{$\begin{array}{l}\chi^{2}=99.730 \\
p \leq .001\end{array}$} \\
\hline & Post & $42(21.5)$ & $80(41.0)$ & $9(4.6)$ & $28(14.4)$ & $36(18.5)$ & \\
\hline \multirow{2}{*}{$\begin{array}{l}\text { 6. Young researchers should receive milder } \\
\text { punishment for plagiarism }\end{array}$} & Pre & $14(7.2)$ & $17(8.7)$ & $16(8.2)$ & 74 (37.9) & 74 (37.9) & \multirow{2}{*}{$\begin{array}{l}\chi^{2}=95.240 \\
p \leq .001\end{array}$} \\
\hline & Post & $31(15.9)$ & $92(47.2)$ & $10(5.1)$ & $35(17.9)$ & $27(13.8)$ & \\
\hline \multirow{2}{*}{$\begin{array}{l}\text { 7. If one cannot write well in a foreign language, it is } \\
\text { justified to copy parts of a similar paper already } \\
\text { published in that language }\end{array}$} & Pre & $9(4.6)$ & $17(8.7)$ & $17(8.7)$ & $72(36.9)$ & $80(41.0)$ & \multirow{2}{*}{$\begin{array}{l}\chi^{2}=102.23 \\
p \leq .001\end{array}$} \\
\hline & Post & $23(11.8)$ & $99(50.8)$ & $8(4.1)$ & $30(15.4)$ & $35(17.9)$ & \\
\hline \multirow{2}{*}{$\begin{array}{l}\text { 8. I could not write a scientific paper without } \\
\text { plagiarizing }\end{array}$} & Pre & $15(7.7)$ & $12(6.2)$ & $20(10.3)$ & $70(35.9)$ & $78(40.0)$ & \multirow{2}{*}{$\begin{array}{l}\chi^{2}=90.210 \\
p \leq .001\end{array}$} \\
\hline & Post & $75(38.5)$ & $45(23.1)$ & $11(5.6)$ & $36(18.5)$ & $28(14.4)$ & \\
\hline \multirow{2}{*}{$\begin{array}{l}\text { 9. Short deadlines give me the right to plagiarize a } \\
\text { bit }\end{array}$} & Pre & $22(11.3)$ & $47(24.1)$ & $37(19.0)$ & $51(26.2)$ & $38(19.5)$ & \multirow{2}{*}{$\begin{array}{l}\chi^{2}=60.630 \\
p \leq .001\end{array}$} \\
\hline & Post & 74 (37.9) & $67(34.4)$ & $15(7.7)$ & $21(10.8)$ & $18(9.2)$ & \\
\hline \multirow{2}{*}{$\begin{array}{l}\text { 10. When I do not know what to write, I translate a } \\
\text { part of a paper from a foreign language }\end{array}$} & Pre & $15(7.7)$ & $21(10.8)$ & $24(12.3)$ & 87 (44.6) & $48(24.6)$ & \multirow{2}{*}{$\begin{array}{l}\chi^{2}=81.450 \\
p \leq .001\end{array}$} \\
\hline & Post & $59(30.3)$ & $72(36.9)$ & $8(4.1)$ & $36(18.5)$ & $20(10.3)$ & \\
\hline \multirow{2}{*}{$\begin{array}{l}\text { 11. It is justified to use one's own previously } \\
\text { published work without providing citation in order } \\
\text { to complete the current work }\end{array}$} & Pre & $13(6.7)$ & $23(11.8)$ & $16(8.2)$ & $71(36.4)$ & $72(36.9)$ & \multirow{2}{*}{$\begin{array}{l}\chi^{2}=95.800 \\
p \leq .001\end{array}$} \\
\hline & Post & $22(11.3)$ & $106(54.4)$ & $11(5.6)$ & $33(16.9)$ & $23(11.8)$ & \\
\hline \multirow{2}{*}{$\begin{array}{l}\text { 12. If a colleague of mine allows me to copy from } \\
\text { his/her paper, I'm NOT doing anything bad, because } \\
\text { I have his/her permission }\end{array}$} & Pre & $27(13.8)$ & $44(22.6)$ & $26(13.3)$ & $65(33.3)$ & $33(16.9)$ & \multirow{2}{*}{$\begin{array}{l}\chi^{2}=58.880 \\
p \leq .001\end{array}$} \\
\hline & Post & $36(18.5)$ & $105(53.8)$ & $17(8.7)$ & $31(15.9)$ & $6(3.1)$ & \\
\hline
\end{tabular}

Table 4. Frequency distribution of the negative attitude towards plagiarism of the studied sample pre- and post- the training workshop

\begin{tabular}{|c|c|c|c|c|c|c|c|}
\hline \multirow{2}{*}{ Items of negative Attitude } & \multirow{2}{*}{ SG } & \multirow{2}{*}{$\begin{array}{l}\text { SD } \\
\mathrm{N}(\%)\end{array}$} & \multirow{2}{*}{$\begin{array}{l}\mathrm{D} \\
\mathrm{N}(\%)\end{array}$} & \multirow{2}{*}{$\begin{array}{l}\text { Either } \\
\text { N (\%) }\end{array}$} & \multirow{2}{*}{$\begin{array}{l}\mathrm{A} \\
\mathrm{N}(\%)\end{array}$} & \multirow{2}{*}{$\begin{array}{l}\text { SA } \\
\mathrm{N}(\%)\end{array}$} & \multirow{2}{*}{$\begin{array}{l}\text { Significance } \\
\text { test }\end{array}$} \\
\hline & & & & & & & \\
\hline \multirow{2}{*}{ 13. Plagiarists do not belong in the scientific community } & Pre & $71(36.4)$ & $67(34.4)$ & $8(4.1)$ & $28(14.4)$ & $21(10.8)$ & $\chi^{2}=88.550$ \\
\hline & Post & $23(11.8)$ & $25(12.8)$ & $6(3.1)$ & $83(42.6)$ & $58(29.7)$ & $p \leq .001$ \\
\hline \multirow{2}{*}{$\begin{array}{l}\text { 14. The name of the authors who plagiarize should be } \\
\text { disclosed to the scientific community }\end{array}$} & Pre & $88(45.1)$ & $63(32.3)$ & $6(3.1)$ & $17(8.7)$ & $21(10.8)$ & $\chi^{2}=102.51$ \\
\hline & Post & $30(15.4)$ & $24(12.3)$ & $6(3.1)$ & $82(42.1)$ & $53(27.2)$ & $p \leq .001$ \\
\hline \multirow{2}{*}{$\begin{array}{l}\text { 15. In times of moral and ethical decline, it is important to } \\
\text { discuss issues like plagiarism and self- plagiarism }\end{array}$} & Pre & $73(37.4)$ & $69(35.4)$ & $9(4.6)$ & $27(13.8)$ & $17(8.7)$ & $\chi^{2}=90.330$ \\
\hline & Post & $32(16.4)$ & $20(10.3)$ & $7(3.6)$ & $87(44.6)$ & $49(25.1)$ & $p \leq .001$ \\
\hline \multirow{2}{*}{ 16. Plagiarizing is as bad as stealing/cheating in an exam } & Pre & $75(38.5)$ & $69(35.5)$ & $16(8.2)$ & $21(10.8)$ & $14(7.2)$ & $\chi^{2}=100.06$ \\
\hline & Post & $25(12.8)$ & $28(14.4)$ & $10(5.1)$ & $78(40.0)$ & $54(27.7)$ & $p \leq .001$ \\
\hline \multirow{2}{*}{ 17. Plagiarism impoverishes the investigative spirit } & Pre & $89(45.6)$ & $57(29.2)$ & $9(4.6)$ & $27(13.8)$ & $13(6.7)$ & $\chi^{2}=94.140$ \\
\hline & Post & $33(16.9)$ & $23(11.8)$ & $5(2.6)$ & $70(35.9)$ & $64(32.8)$ & $p \leq .001$ \\
\hline \multirow{2}{*}{ 18. A plagiarized paper does no harm to science } & Pre & $11(5.6)$ & $39(20.0)$ & $22(11.3)$ & $82(42.1)$ & $41(21.0)$ & $\chi^{2}=65.380$ \\
\hline & Post & $12(6.2)$ & $107(54.9)$ & $28(14.4)$ & $31(15.9)$ & $17(8.7)$ & $p \leq .001$ \\
\hline \multirow{2}{*}{ 19. Plagiarism NOT be considered as a serious offense } & Pre & $34(17.4)$ & $90(46.2)$ & $24(12.3)$ & $29(14.9)$ & $18(9.2)$ & $\chi^{2}=63.250$ \\
\hline & Post & $14(7.2)$ & $38(19.5)$ & $22(11.3)$ & $86(44.1)$ & $35(17.9)$ & $p \leq .001$ \\
\hline
\end{tabular}


Table 5. Frequency distribution of the subjective norms attitude towards plagiarism of the studied sample pre- and post- the training workshop

\begin{tabular}{|c|c|c|c|c|c|c|c|}
\hline \multirow{2}{*}{ Subjective Norms } & \multirow{2}{*}{ SG } & \multirow{2}{*}{$\begin{array}{l}\text { SD } \\
\text { N (\%) }\end{array}$} & \multirow{2}{*}{$\begin{array}{l}\text { D } \\
\text { N (\%) }\end{array}$} & \multirow{2}{*}{$\begin{array}{l}\text { Either } \\
\mathrm{N}(\%)\end{array}$} & \multirow{2}{*}{$\begin{array}{l}\text { A } \\
\mathrm{N}(\%)\end{array}$} & \multirow{2}{*}{$\begin{array}{l}\text { SA } \\
N(\%)\end{array}$} & \multirow{2}{*}{$\begin{array}{l}\text { Significance } \\
\text { test }\end{array}$} \\
\hline & & & & & & & \\
\hline \multirow{2}{*}{$\begin{array}{l}\text { 20. Authors say they do NOT plagiarize, when in } \\
\text { fact they do }\end{array}$} & Pre & $47(24.1)$ & $68(34.9)$ & $33(16.9)$ & $33(18.5)$ & $11(5.6)$ & $\chi^{2}=47.220$ \\
\hline & Post & $39(20.0)$ & $79(40.5)$ & $71(36.4)$ & $5(2.6)$ & $1(0.5)$ & $p \leq .001$ \\
\hline \multirow{2}{*}{$\begin{array}{l}\text { 21.Those who say they have never plagiarized are } \\
\text { lying }\end{array}$} & Pre & $7(3.6)$ & $25(12.8)$ & $23(11.8)$ & $70(35.9)$ & $70(35.9)$ & $\chi^{2}=120.240$ \\
\hline & Post & $5(2.6)$ & $65(33.3)$ & $88(45.1)$ & $27(13.8)$ & $10(5.1)$ & $p \leq .001$ \\
\hline \multirow{2}{*}{$\begin{array}{l}\text { 22. Sometimes I'm tempted to plagiarize, because } \\
\text { everyone else is doing it }\end{array}$} & Pre & $11(5.6)$ & $26(13.3)$ & $6(3.1)$ & $77(39.5)$ & $75(38.5)$ & $\chi^{2}=135.500$ \\
\hline & Post & $14(7.2)$ & $72(36.9)$ & $66(33.8)$ & $29(14.9)$ & $14(7.2)$ & $p \leq .001$ \\
\hline \multirow{2}{*}{$\begin{array}{l}\text { 23. I keep plagiarizing because I haven't been } \\
\text { caught yet }\end{array}$} & Pre & $19(9.7)$ & $15(7.7)$ & $8(4.1)$ & $79(40.5)$ & 74 (37.9) & $\chi^{2}=124.790$ \\
\hline & Post & $26(13.3)$ & $105(53.8)$ & $13(6.7)$ & $36(18.5)$ & $15(7.7)$ & $p \leq .001$ \\
\hline \multirow{2}{*}{ 24. I work in a plagiarism-free environment } & Pre & $23(11.8)$ & $19(9.7)$ & $21(10.8)$ & $73(37.4)$ & $59(30.3)$ & $\chi^{2}=102.630$ \\
\hline & Post & $32(16.4)$ & $101(51.8)$ & $17(8.7)$ & $31(15.9)$ & $14(7.2)$ & $p \leq .001$ \\
\hline \multirow{2}{*}{ 25. Plagiarism is not a big deal } & Pre & $44(22.6)$ & $80(41.0)$ & $31(15.9)$ & $31(15.9)$ & $9(4.6)$ & $\chi^{2}=33.040$ \\
\hline & Post & $35(17.9)$ & $68(34.5)$ & $77(39.5)$ & $11(5.6)$ & $4(2.1)$ & $p \leq .001$ \\
\hline \multirow{2}{*}{$\begin{array}{l}\text { 26. Sometimes I copy a sentence or two just to } \\
\text { become inspired for further writing }\end{array}$} & Pre & $12(6.2)$ & $39(20.0)$ & $31(15.9)$ & $86(44.1)$ & $27(13.8)$ & $\chi^{2}=62.950$ \\
\hline & Post & $9(4.6)$ & $67(34.4)$ & $78(40.0)$ & $35(17.9)$ & $6(3.1)$ & $p \leq .001$ \\
\hline \multirow{2}{*}{$\begin{array}{l}\text { 27. I don't feel guilty for copying verbatim } \\
\text { sentence or two from my previous papers }\end{array}$} & Pre & $7(3.6)$ & $18(9.2)$ & $16(8.2)$ & $91(46.7)$ & $63(32.3)$ & $\chi^{2}=116.520$ \\
\hline & Post & $15(7.7)$ & $106(54.4)$ & $18(9.2)$ & $44(22.6)$ & $12(6.2)$ & $p \leq .001$ \\
\hline \multirow{2}{*}{$\begin{array}{l}\text { 28. Plagiarism is justified if I currently have more } \\
\text { important obligations or tasks to do }\end{array}$} & Pre & $5(2.6)$ & $31(15.9)$ & $13(6.7)$ & $77(39.5)$ & $69(35.5)$ & $\chi^{2}=104.340$ \\
\hline & Post & $13(6.7)$ & $115(59.0)$ & $18(9.2)$ & $33(16.9)$ & $16(8.2)$ & $p \leq .001$ \\
\hline \multirow{2}{*}{ 29. Sometimes it is necessary to plagiarize } & Pre & $11(5.6)$ & $22(11.3)$ & $27(13.8)$ & $69(35.4)$ & $66(33.8)$ & $\chi^{2}=123.190$ \\
\hline & Post & $32(16.4)$ & $91(46.7)$ & $40(20.5)$ & $25(12.8)$ & $7(3.6)$ & $p \leq .001$ \\
\hline
\end{tabular}

Table 6. Average attitudes score of the studied sample towards plagiarism pre- and post- the training workshop

\begin{tabular}{llll}
\hline \multirow{2}{*}{ Items } & Pre-training & Post-training & Paired $\boldsymbol{t}$ test \\
\cline { 2 - 4 } & Mean \pm SD & Mean \pm SD & $t=13.821, p \leq .001$ \\
\hline Positive attitude scores & $43.06 \pm 8.28$ & $31.48 \pm 10.51$ & $t=14.017, p \leq .001$ \\
Negative attitude scores & $16.83 \pm 5.33$ & $23.95 \pm 6.18$ & $t=16.879, p \leq .001$ \\
Subjective norms scores & $35.23 \pm 6.43$ & $25.69 \pm 7.27$ & $t=12.446, p \leq .001$ \\
Total attitudes scores & $95.12 \pm 11.71$ & $81.12 \pm 13.83$ & $t$ \\
\hline
\end{tabular}

Figure 3 shows the level of the positive attitudes toward pla- level of positive attitude was significantly increased after the giarism pre- and post-workshop, the percentage of the low training (63.1\%) compared to $10.8 \%$ before it.

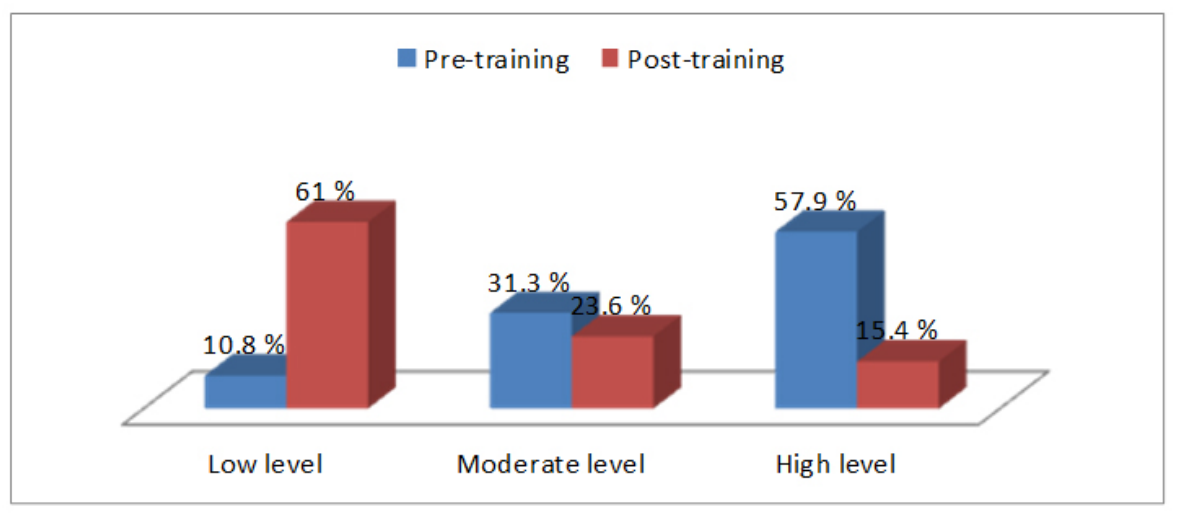

Figure 3. Level of the positive attitude towards plagiarism among the studied sample pre- and post- the training workshop 
Figure 4 shows the level of the negative attitudes towards plagiarism pre- and post- the training, the percentage of the high level of negative attitude was significantly increased after the training (57.9\%) compared to $7.7 \%$ before it.

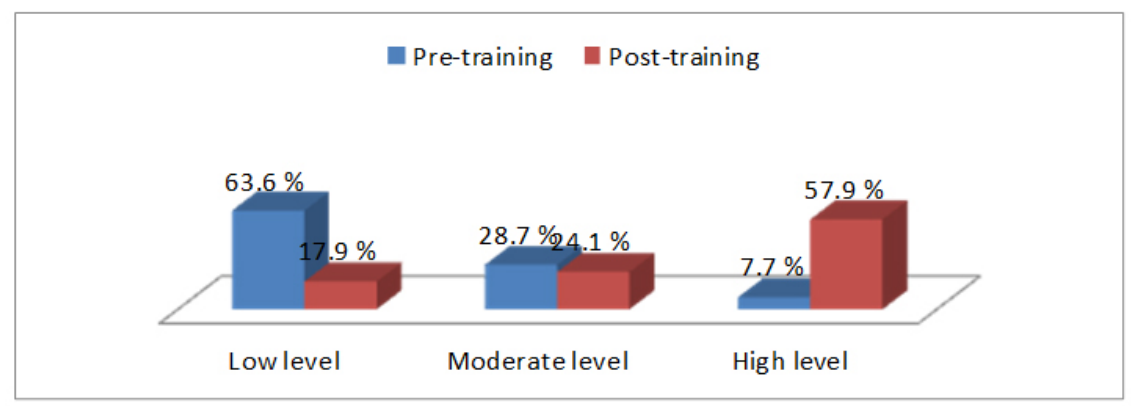

Figure 4. Level of the negative attitude towards plagiarism among the studied sample pre- and post- the training workshop

Figure 5 shows the Level of the subjective norms attitudes towards plagiarism pre- and post- the training workshop, the percentage of the low level of subjective norms attitude was significantly increased after the training (54.4\%) compared to $6.7 \%$ before it.

Table 7 shows the correlation between the total knowledge score, practical scenario score and attitudes scores toward plagiarism among the studied sample. It shows a signifi- cant positive moderate correlation between knowledge score of the studied subjects about plagiarism and their practical scenario solving score $(r=0.346, p \leq .001)$. It was shown that there was significant mild correlation between the total knowledge score and positive, subjective norms and total attitude scores of the studied sample towards plagiarism, while there was a significant positive mild correlation between the total knowledge score and the negative attitude of the studied sample towards plagiarism $(r=0.254, p \leq .001)$.

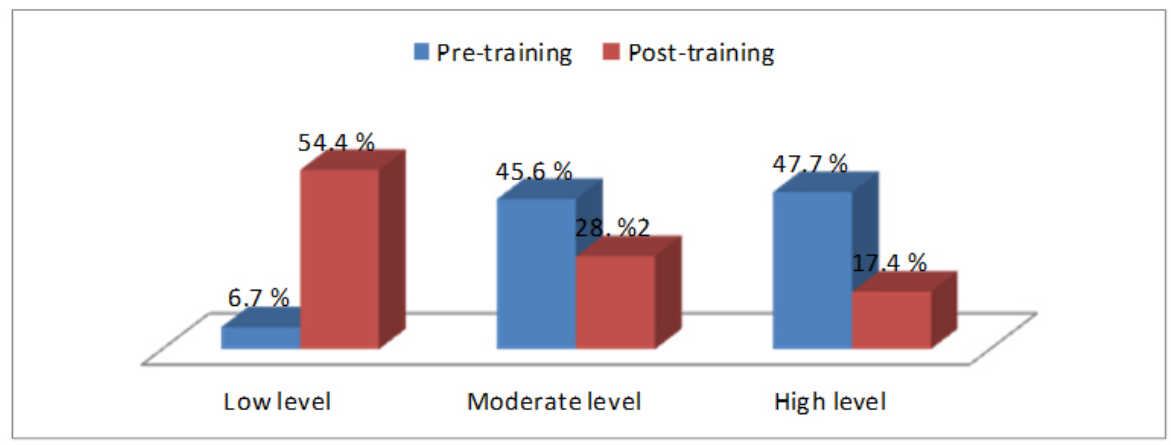

Figure 5. Level of the subjective norms attitude towards plagiarism among the studied sample pre- and post- the training workshop

Table 7. Correlation between total knowledge score \& practical scenario score and attitudes score towards plagiarism among the studied sample

\begin{tabular}{lll}
\hline \multirow{2}{*}{ Variables } & \multicolumn{2}{l}{ Total knowledge score } \\
\cline { 2 - 3 } & $\boldsymbol{r}$ & $\boldsymbol{p}$ \\
\hline Practical scenario scores & 0.346 & $\leq .001$ \\
Positive attitude scores & -0.195 & $\leq .01$ \\
Negative attitude scores & 0.254 & $\leq .001$ \\
Subjective norms attitude scores & -0.231 & $\leq .001$ \\
Total attitudes scores & -0.150 & $\leq .05$ \\
\hline
\end{tabular}

Figure 6 shows significant mild negative correlation with Published by Sciedu Press the total knowledge score and the total attitude score of the studied sample towards plagiarism $(r=-0.150, p \leq .05)$.

\section{Discussion}

The study was aimed to improve the knowledge, skills and attitudes of the nursing faculty members and postgraduate students towards plagiarism in academic writing. The findings of the present study had significantly accepted the research hypothesis where the findings showed that the average score of the participants' knowledge scores and their practical scenario-solving scores about plagiarism were significantly increased after the workshop compared to their levels before 
it. Furthermore, there was statistically significant change in the participant's attitudes towards plagiarism, where the average scores of the positive attitude, subjective norms and total attitude score were significantly decreased, while the average score of the negative attitude significantly increased after the educational and training workshop in comparison to before it.

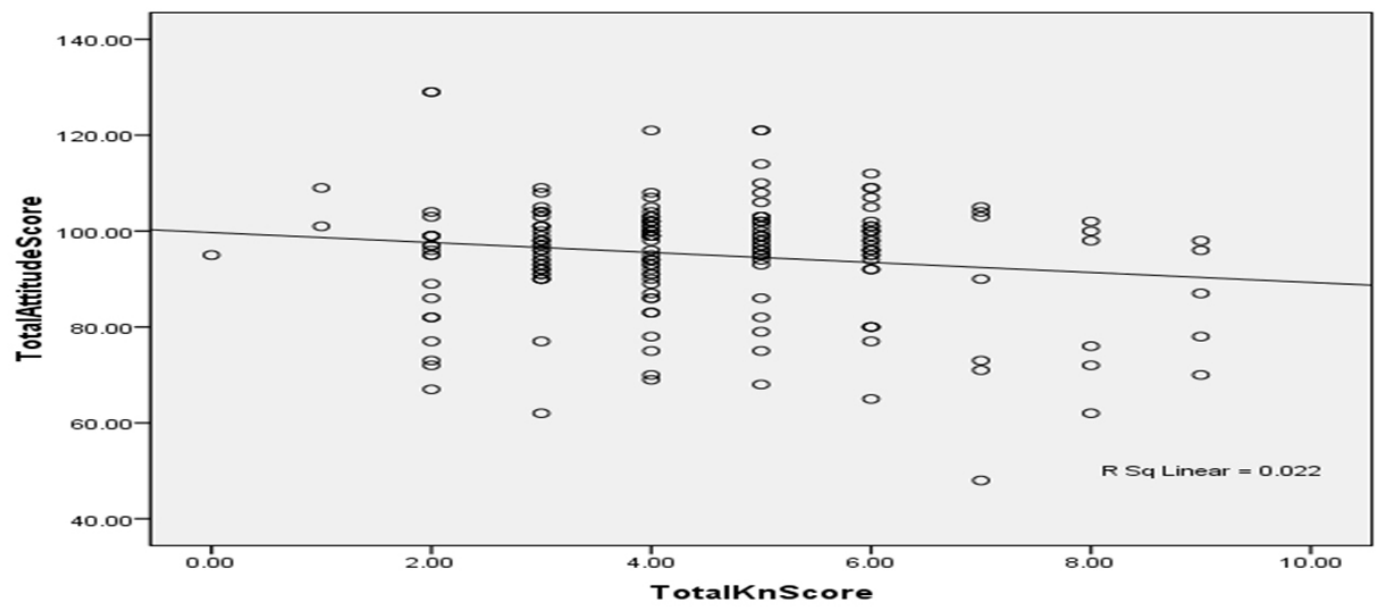

Figure 6. Correlation between the total knowledge score and the total attitudes (ATP) score

The present study findings revealed that the average knowledge score of the studied sample towards plagiarism significantly increased after the training compared to their average scores before. This result could be due to the educational intervention that correlated with utilization of interactive teaching materials and methods, which included the theoretical and practical sessions. These methods helped to increase the understanding of the participants and permit them to engage in each part of the sessions, in addition to their essential desire to acquire scientific knowledge regarding plagiarism.

This result is in accordance with Pence ${ }^{[18]}$ a pioneer study in scrutinizing the effect of providing nursing students with scientific writing materials, which confirmed that this helped in growing mindfulness on plagiarism.

These results were in agreement with $\mathrm{Hu}^{[19]}$ who studied the knowledge and attitude of Chinese students towards plagiarism in Singapore and stated that the students had little ability to detect plagiarism at the beginning of training. However, after the training, the students' knowledge towards plagiarism was significantly improved due to their exposure to higher education, lesser acceptance to plagiarism and the improvement of the ability to determine the verbatim copying.

Similarly, Wan et al. ${ }^{[20]}$ results found that most of students (about 63\%) were known little and twenty percentage of them reported that they have never been told about plagiarism and their lack of awareness toward plagiarism seems to be one of the most reasons of misconduct among the Nigerian academic system. However, the current results were inconsistent with Ryan et al. ${ }^{[21]}$ results in Australia who study the knowledge and awareness of students about plagiarism, reported that the awareness level was high while the knowledge level was low.

In addition, Ramzan et al. ${ }^{[22]}$ supported these findings in their study conducted in Pakistan about the awareness of university students about plagiarism and stated that the awareness level of the postgraduate students toward plagiarism was poor, which indicates that they do not understand the concepts of plagiarism and the policies are used for detecting it. Likewise, Fierz et al. ${ }^{[23]}$ studied the awareness level as well as the understanding of the plagiarism concept and mentioned that the participants' understanding of the plagiarism concept is limited.

Moreover, the present study results revealed an increase in the average practical score of the studied sample towards plagiarism after the intervention in comparison to before it. This was because some of the participants were aware about plagiarism but did not know the actions that constitute plagiarism reduction. However, the guidance and education that were given to the participants for emphasizing the ethical, rather than the punitive aspects of plagiarism as well as to improve their skills about paraphrasing and guidance scenarios.

A study accomplished at the San José State University by Jackson $^{[24]}$ presented that the students had inability to apply the concept of paraphrasing in practice; they consequently need extra chances for training to practice paraphrasing to 
be able to apply it in their texts. In addition, these results were supported by Idiegbeyanose et al. ${ }^{[25]}$ results who found a significant positive relationship at $r=0.294$ and $p<.05$, between knowledge and practice that implies when awareness increases, practices will also improve.

Concerning the positive attitude of the studied sample towards plagiarism before the workshop, the results showed that more than half of them were agreed that the one could not avert using other author's text without citing the original source. Meanwhile, after training they become disagreed, these results could be associated with the clearness of the meaning and the concept of plagiarism. This result was in agreement with Kirthi et al., ${ }^{[26]}$ in their study conducted in India about attitude of faculty staff and postgraduate student's toward plagiarism. It was stated that about half of them were agreed that the one could not avoid using other people's words without citing the source. Similarly, Park et al. ${ }^{[27]}$ in their study conducted in Korean about academic cheating among Korean nursing students and reported that about half of the students supposed there is no problem with copying some statements from another work without citing the author in the article.

On the other hand, the findings of the present study revealed that the majority of the studied sample was agreed that selfplagiarism is not punishable because it is not harmful and should not be punishable in the same way as plagiarism, and strongly agreed that they could not write a scientific paper without plagiarizing. These results were supported by Pupovac et al. ${ }^{[13]}$ in their study conducted in Croatia for evaluating the medical student's ATP and stated that more than half of the students were agreed that plagiarized paper does no harm to science and self-plagiarism should not be considered harm.

In relation to the negative attitude of the studied sample, the present study findings revealed change in the negative attitude in favor of after the workshop. More than half of the participants were agreed that plagiarists do not belong in the scientific community, the name of the authors who plagiarize should be disclosed to the scientific community and were agreed that plagiarizing is as bad as stealing/cheating in an exam. Likewise, more than half of them were disagreed that a plagiarized paper does no harm to science. The finding of the present study proved that the majority of participants refused plagiarism post workshop. This is an expected outcome, as they recognize that plagiarism is not accepted action and it is a type of research misconduct.

These results were supported by Shimi et al. ${ }^{[28]}$ and Jain et al. ${ }^{[29]}$ who reported that more than half of postgraduate students and academic staff were agreed that plagiarizing is as bad as stealing/cheating in an exam. However, Hosny \& Fatima ${ }^{[30]}$ supported these findings in the study performed to investigate student's attitude toward academic plagiarism and cheating in kingdom of Saudi Arabia and reported that $81.0 \%$ of the students believed that plagiarism is bad like cheating in an exam.

Concerning the subjective norms attitude of the studied sample before intervention, the study findings showed that more than three fourths of them were strongly agreed that they tempted to plagiarize, because everyone else is doing it. In addition, they were strongly agreed to keep plagiarizing because they have not been caught yet and believed they sometimes need to copy a sentence or two just to become inspired for further writing. Moreover, they were agreed that they do not feel guilty for copying verbatim a sentence or two from their previous papers and more than one third agreed that sometimes it is necessary to plagiarize. These findings contradicted with Kirthi et al. ${ }^{[26]}$ in their study conducted in Telangana to investigate the postgraduate students ATP. It was stated that more than one third of the faculty staff members and postgraduate students did not agree that they are sometimes tempted to plagiarize. This is because everyone else is doing it and disagreed to keep plagiarizing because they have not been caught yet.

With respect to their guilty feeling for copying verbatim sentence or two from previous papers, the current study results revealed that there was significant change regarding the participant's subjective norms attitude, whereas more than half of the participants were disagreed regarding they don't feel guilty for copying in comparison to pre-the workshop. In addition, more than half of them were disagreed that they are working in an environment that is free from plagiarism. This result could be associated with some constrains associated with their limited time and the work pressure in addition to the inconspicuous concept of plagiarism. Pupovac et al. ${ }^{[13]}$ contradicted these results and stated that half of their subjects were working in an environment free from plagiarism.

On the other hand, the current study results indicated a significant decrease in the mean score of the positive attitude and subjective norms attitude as well as increase in the mean score of the negative attitude after implementation of the training workshop in comparison to before it. Consequently, it is important to realize that the positive attitude reveals the plagiarism acceptance and the negative attitude reveals denunciation of actions toward plagiarism. Therefore, these results indicate decrease in their acceptance level towards plagiarism and increase their disapproval for any actions that empower plagiarism in scientific papers. Additionally, these results indicated that there is an improvement of participant's 
perception towards plagiarism and modifications of misinterpretation in paraphrasing of scientific work, methodology and scientific misconduct that reflect increased their level of seriousness and awareness regarding plagiarism and in how it is perceived. In addition to the participant's motivation to know, correct and adopt the right manners in plagiarism.

These results were inconsistent with the previous study results by Pupovac et al, ${ }^{[13]}$ implemented in Croatia and stated that about $65 \%$ of medical students were found justified and accepted toward plagiarism. Similarly, Razera et al. ${ }^{[31]}$ who found that lack of motivation, poorly worded examinations, and lack of training in scientific writings were some of the factors that forced students towards plagiarism.

While Shimi et al. ${ }^{[28]}$ and Pupovac et al. ${ }^{[13]}$ stated in their study that was conducted in Croatia to evaluate the attitude of medical students towards plagiarism that there was no clear attitude towards plagiarism, and this result indicated that, however, they aware of plagiarism but they support and vindicate plagiarism even though they know that it is wrong.

Mones ${ }^{[32]}$ stated in the study that conducted to assess Knowledge, skills and attitudes of college's students toward plagiarism in the Philippines, that $19.1 \%$ of students had positive attitude and $28.2 \%$ of them had negative attitude response. Meanwhile, $52.7 \%$ of the students had a neutral attitude towards plagiarism.

These study findings were similar to the result obtained by Rathore et al. ${ }^{[3]}$ in their study conducted to explore the medical staff ATP in Pakistan. The study discovered that the majority of the studied subjects had moderate or high score of plagiarism attitude and the lower scores of their ATP were correlated with training sessions about scientific writing skills and research ethics.

Additionally, the results clarified that there was a statistically significant positive correlation between the knowledge and practical scenarios score. Moreover, there was significant negative mild correlation between the total knowledge score and the positive, subjective norms and the total attitude scores. Meanwhile, there was a significant positive mild correlation between total knowledge score and the negative attitude of the studied sample towards plagiarism. These results clarify that the participants have acquired the basic knowledge and training that enable them to cite the provided information while avoiding plagiarism and they become able to determine the degree to which original provenance could be used literal and how it can be avoided.

Accordingly, these results clarify that there is a significant relation between the knowledge level and skills in addition to the lack of plagiarism awareness among the participants, accompanying with serious consequences. It explains the effectiveness and benefits of the workshop for improving the participant's knowledge and skills and changing their ATP with emphasis on ethical issue in scientific writing.

These results were concordant with Kirthi et al. ${ }^{[26]}$ found their participants have moderate attitude towards plagiarism and correlate these findings as a serious consequence of lack of awareness and its effect on the scientific article's originality. These results were also congruous with Ryan et al. ${ }^{[21]}$ who highlighted that it is very difficult to change the attitude and improve the competences through the educational process without effective training regarding scientific writing, follow rules that strict use of plagiarism and improvement of knowledge regarding the academic integrity. Likewise, Lee $\&$ Partridge ${ }^{[34]}$ were in agreement with these findings and reported that there was an improvement of their students' performance toward plagiarism especially in paraphrasing and assignment referencing after the educational intervention.

Meanwhile, Bristol, ${ }^{[35]}$ and Karabag \& Berggren ${ }^{[36]}$ stated that educational intervention could increase the student's knowledge and improve their understanding of plagiarism. Consequently, these findings have implications for any future changes in the educational intervention and further research in this area could provide a broad understanding of the students' abilities.

Furthermore, previous study conducted by Hrabak et al. ${ }^{[37]}$ stated that the cultural environment and the moral values in their communities influence the individual's attitudes and behaviors. Thus, increasing the rate of acceptance of plagiarism and cheating in some communities is considered an evident for increasing the rate of corruption.

\section{Conclusion}

As has been noted, the current study results concluded that there was a statistically significant improvement in knowledge and skills of the nursing faculty members and postgraduate students with a significant change in their attitudes towards plagiarism after implementation of the workshop.

\section{Recommendations}

According to the study findings, the study recommended:

- Providing continuing educational and training programs for newly faculty members and researchers to improve their scientific writing skills, research ethics and for highlighting plagiarism and its consequences.

- Academic integrity should have more attention in order to confirm restriction of academic dishonesty opportunities.

- Develop guidelines on editing and proofreading for 
project and scientific researches.

- Faculties should keep itself updated about the modern strategies concerning plagiarism inside the university and the country.

- Further studies about evaluation of the factors associated with plagiarism and alternative training methods that help in limiting this behavior.

\section{ACKNOWLEDGeMENTS}

Great thanks to all the faculty members and postgraduate students at Nursing Faculty in Mansoura University for their attendance and participation throughout the study period.

\section{Conflicts of InTEREST Disclosure}

The researchers declare that there is no conflict of interest in the research.

\section{REFERENCES}

[1] Oxford English Dictionary. Plagiarism. 2010. Available from: http: //www. oed.com/view/Entry/144939

[2] O'Connor Z. Extreme plagiarism: The rise of the e-Idiot. International Journal of Learning in Higher Education. 2015; 20(1): 1-11.

[3] Gow S. A Cultural Bridge for Academic Concept of Plagiarism: A Comparison of Chinese and British Cultural Concepts of Plagiarism by Chinese Master's Graduate of UK Institutions Employed by Sino-Foreign Joint Ventures in Shanghai, China. In Conference Proceeding, Plagiarism across Europe and Beyond. Held between June 12- 13 at Brno, Czech Republic. 2013. Available from: https: //plagiarism.pefka.mendelu.cz/files/proceedings.pdf

[4] Orim S, Borg E, Awala-Ale I. Students' Experience on Institutional Interventions on Plagiarism: Nigerian Case. In Conference Proceeding, Plagiarism across Europe and Beyond, Held between June 1213 at Brno, Czech Republic. 2013.

[5] Satyanarayana K. Plagiarism: a scourge afflicting the Indian science. Indian J Med Res. 2010; 131: 373-6. PMid:20418548

[6] Ragin S. Plagiarism in Academic Writing: How to Identify and Avoid It. 2016.

[7] Ghajarzadeh M, Norouzi-Javidan A, Hassanpour K, et al. Attitude toward Plagiarism among Iranian Medical Faculty Members. ActaMedicaIranica. 2012; 50(11): 778-781. PMid:23292631

[8] Iparadigms. Turnitin. 2013. Available from: http://turnitin.c om/en_us/home

[9] Walker J. Measuring plagiarism: Researching what students do, not what they say they do. Studies in Higher Education. 2010; 35(1): 41-59. https://doi.org/10.1080/03075070902912994

[10] Woith W, Jenkins S, Kerber C. Perceptions of academic integrity among nursing students. Nursing Forum. 2012; 47(4): 253-259. PMid:23127239 https://doi.org/10.1111/j.1744-6198.20 $12.00274 . \mathrm{x}$

[11] Hayes N, Introna L, Whitley EA. Plagiarism, values and computing: differing cultural expectations of academic work in information systems education. 2010. Available from: http://www.lums. lancs .ac.uk/files/sdaw/5707/download/

[12] Youmans R. Does the adoption of plagiarism-detection software in higher education reduce plagiarism? Studies in Higher Education. 2011; 36(7): 749-761. https://doi .org/10.1080/03075079.2 010.523457

[13] Pupovac V, Bilic L, Mavrinac M, et al. Attitudes toward plagiarism among pharmacy and medical biochemistry students - crosssectional survey study. BiochemiaMedica. 2010; 20(3): 307-13. https://doi.org/10.11613/bm.2010.039

[14] Gomez M, Sh Nagesh L, Sujatha BK. Assessment of the attitude toward plagiarism among dental postgraduate students and faculty members in Bapujj Dental College and Hospital, Davangere-A cross sectional survey. IOSR Journal of Dental and Medical Sciences. 2014; 13(5): 01-06.

[15] Smedley A, Crawford T, Cloete L. An intervention aimed at reducing plagiarism in undergraduate nursing students. Nurse Education in Practice. 2015; 15: 168-173. PMid:25578380 https: //doi.org/10.1016/j.nepr.2014.12.003

[16] Mavrinac M, Brumini G, Bilić-Zulle L, et al. Construction and Validation of Attitudes toward Plagiarism Questionnaire. Croat Med J. 2010; 51(3): 195-201. https://doi.org/10.3325/cmj . 2010.5 1.195

[17] Dawson M, Overfield J. Plagiarism: Do Students Know What It Is? Bioscience Education. 2006; 8(1): 1-15. https://doi.org/10.3 108/beej. 8.1

[18] Pence PL. Plagiarism: Using a collaborative approach in an online allied health professions course. Nurse Educator. 2012; 37(1): 12-16 PMid:22157995 https://doi.org/10.1097/NNE.0b013e3182 383701

[19] Hu G. Investigating Chinese University Students' Knowledge of and Attitudes toward Plagiarism from an Integrated Perspective. Journal of Research in Language Studies. 2012; 62(3): 813-850.

[20] Wan R, Nordin S, Halib M, et al. Plagiarism among undergraduate students in an Engineering-based university: An exploratory analysis European Journal of Social Sciences. 2011; 2(4): 201, 537-549.

[21] Ryan G, Bonanno H, Krass I, et al. Undergraduate and postgraduate pharmacy students' perceptions of plagiarism and academic honesty. Am J Pharm Educ. 2009; 73: 105. PMid:19885074 https: //doi.org/10.5688/aj7306105

[22] Ramzan M, Munir MA, Siddique N, et al. Awareness about plagiarism amongst university students in Pakistan. Higher Education. 2012; 64(1): 73-84. https://doi.org/10.1007/s10734-011 $-9481-4$

[23] Fierz K, Gennaro S, Dierickx K, et al. Scientific misconduct: Also an issue in Nursing Science. Journal of Nursing Scholarship. 2014; 46(4): 271-80. PMid:24758524 https://doi.org/10.1111/jnu. 12082

[24] Jackson P. Plagiarism instruction online: Assessing undergraduate students' ability to avoid plagiarism. College \& Research Libraries 2006; 67(5): 418-428. https ://doi.org/10.5860/crl.67.5.4 18

[25] Idiegbeyanose J, Nkiko C, Osinulu I. Awareness and Perception of Plagiarism of Postgraduate Students in Selected Universities in Ogun State, Nigeria. University of Nebraska - Lincoln DigitalCommons@University of Nebraska - Lincoln. Library Philosophy and Practice (e-journal). 2016. Available from: http://digitalcommo ns.unl.edu/libphilprac/1322

[26] Kirthi P, Pratap K, Padma T, et al. Attitudes towards Plagiarism among Post-Graduate Students and Faculty Members of a Teaching Health Care Institution in Telangana - A cross-sectional questionnaire 
based study. International Journal of Advanced Research. 2015; 3(8): 1257-1263.

[27] Park E, Park S, Jang I. Academic cheating among nursing students. Nurse Education Today. 2013; 33: 346-352. PMid:23357719 https://doi.org/10.1016/j.nedt.2012.12.015

[28] Shimi M, Gomez S, Nagesh L, et al. Assessment of the attitudes towards Plagiarism among dental postgraduate students and faculty members in Bapuji Dental College and Hospital, Davangere - A cross sectional survey. IOSR Journal of Dental and Medical Sciences. 2014; 13: 1-6.

[29] Jain S, Saxena V, Hongal S, et al. Comparison of Opinion Referendum of Medical and Dental Postgraduates towards Plagiarism in Bhopal - Central India. Journal of the College of Physicians and Surgeons Pakistan. 2015; 25: 514-8. PMid:26208556

[30] Hosny M, Fatima S. Attitude of students towards cheating and plagiarism: University case study. Journal of Applied Science. 2014; 14(8): 748-757. https://doi.org/10.3923/jas.2014.748.757

[31] Razera D, Verhagen H, Pargman TC, et al. Plagiarism awareness, perception, and attitudes among students and teachers in Swedish higher education - cases study. Paper Presented at the 4th International Plagiarism Conference-Towards an authentic future. North Umbria University in Newcastle Upon Tyne-UK. 2010.

[32] Mones R. College students' information exposure, knowledge and attitude towards plagiarism, and their practices in using print and online reference materials. Unpublished BS Development Communication Thesis. Visayas State University, Baybay, Leyte. Philippines. 2013.

[33] Rathore F, Waqas A, Zia A, et al. Exploring the attitudes of medical faculty members and students in Pakistan towards plagiarism: a cross sectional survey. PeerJ. 2015. https://doi.org/10.7717/peer j. 1031

[34] Lee J, Partridge L. Evaluating the effectiveness of educational and academic integrity initiatives in higher education. In Educational integrity: Culture and values. Proceedings 5th Asia Pacific Conference on Educational Integrity. The University of Western Australia, 26-28 September. 2011. 82-86 p. Available from: http: //www.apcei.catl.uwa.edu.au/procs/lee.pdf

[35] Bristol TJ. Plagiarism prevention with technology. Teach. Learn. Nurs. 2011; 6: 146-149. https://doi.org/10.1016/j.teln.2 011.05 .002

[36] Karabag SF, Berggren C. Retraction, dishonesty and plagiarism: analysis of a crucial issue for academic publishing, and the inadequate responses from leading journals in economics and management disciplines. Journal of Applied Economics and Business Research. 2012; 2(3): $172-83$

[37] Hrabak M, Vujaklija A, Vodopivec I, et al. Academic misconduct among medical students in a post-communist country. Medical Education. 2004; 38(3): 276-285. PMid:14996337 https ://doi .org/ $10.1111 / j .1365-2923.2004 .01766 . x$ 